PS03 Uloga hitne medicinske pomoći u zbrinjavanju bolesnika s terminalnom fazom bolesti: slučaj iz prakse

Marin Glavčića , Grgur Salai ${ }^{a}$, Miodrag Basta ${ }^{a}$, Slobodanka Keleuva ${ }^{a}$

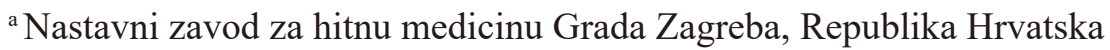

DOI: https://doi.org/10.26800/LV-143-sup13-PS03

Marin Glavčić (0000-0002-9065-4010), Grgur Salai, Miodrag Basta, Slobodanka Keleuva

Ključne riječi: Analgezija, Hitna medicina, Palijativna medicina

UVOD: Hitna medicinska pomoć (HMP), osim zbrinjavanja akutno nastalih i životnougrožavajućih stanja, ima ulogu u pružanju skrbi te očuvanju što veće kvalitete života u terminalno bolesnih. Bolesnikovi se simptomi često ne mogu u kontrolirati bez pomoći medicinskih djelatnika - posebice noću i vikendima, nerijetko se traži pomoć od HMP.

PRIKAZ SLUČAJA: Tim 1 HMP pozvan je u kasnim noćnim satima za muškarca od 56 godina oboljelog od sigmoidnog adenokarcinoma s presadnicama na plućima te kostima rebara i kralježnice, radi nemogućnosti analgezije. Po dolasku HMP, pacijent je bio pri svijesti, orijentiran te urednih vitalnih parametara. Uvidom u medicinsku dokumentaciju potvrđeno je kako se radi o bolesniku u terminalnoj fazi liječenja. Razgovorom s bolesnikom utvrđene su njegove želje vezane za liječenje kod kuće. Bolesnik je trpio neizdrživu bol (10/10 na vizualnoj analognoj skali) te mu supruga nije mogla pomoći regulirati bol lijekovima koji su mu propisani. Osam sati prije dolaska HMP primio je metamizol 500mg p.o. te kombinaciju tramadola $75 \mathrm{mg}$ i ketoprofena $25 \mathrm{mg}$ kao i buprenorfinski flaster $52,5 \mu \mathrm{g} / \mathrm{h}$. U pregledu pacijenta ne nađe se novonastalih patoloških znakova te se pristupi primjeni terapije: pacijentu je intramuskularno primijenjeno $2,5 \mathrm{~g}$ metamizola, $10 \mathrm{mg}$ diazepama, $75 \mathrm{mg}$ ketoprofena te $4 \mathrm{mg}$ deksametazona. Uz navedeno, pacijentu i obitelji pružena je i psihosocijalna pomoć.

ZAKLJUČAK: Iako HMP nije idealno mjesto za liječenje bolesnika s terminalnom fazom bolesti, takve su intervencije česte. Predstavljeni slučaj primjer je intervencije HMP kojoj cilj nije brza stabilizacija akutno ugroženog pacijenta uz brzi transport do bolničke ustanove, već pristup orijentiran prema željama bolesnika uz omogućavanje najbolje moguće kvalitete života u posljednjoj fazi bolesti.

\title{
The Role of Prehospital Emergency Medical Service in Caring for Terminally Ill Patients: A Case Report from Day-to-day Practice
}

Keywords: Analgesia, Emergency medical service, Paliative care

INTRODUCTION: Prehospital emergency medical service (PEMS), besides taking care of acute and life-threatening conditions, has a role in providing care and maintaining the highest possible quality of life in terminally ill people. Patients' symptoms often cannot be controlled without the help of medical professionals - help is often sought from PEMS, especially at night and during weekends. CASE REPORT: Physician-led PEMS team was called during late-night hours for a 56-year-old man with sigmoid adenocarcinoma and lung, costal and spinal metastases due to inadequate analgesia. Upon arrival, the patient was alert, oriented and had normal vital parameters. Review of medical documentation confirmed that the patient was in the terminal phase of treatment. The patient made his wishes regarding treatment at home clear. The patient was suffering unbearable pain (10/10 on a visual analog scale) and his wife could not help him regulate pain with prescribed medications. Eight hours previously, he took metamizole $500 \mathrm{mg}$, a combination of tramadol $75 \mathrm{mg}$ and ketoprofen $25 \mathrm{mg}$ and buprenorphine patch $52.5 \mu \mathrm{g} / \mathrm{h}$. The physical examination was unremarkable and metamizole $2.5 \mathrm{~g}$, diazepam $10 \mathrm{mg}$, ketoprofen $75 \mathrm{mg}$ and dexamethasone $4 \mathrm{mg}$ were administered intramuscularly. Furthermore, the patient and family were provided with psychosocial assistance.

CONCLUSION: Although PEMS is not an ideal way of treating patients with end-stage disease, such interventions are common. The presented case is an example of PEMS interventions whose goals are not to stabilize acutely ill patients with fast transport to a hospital-setting, but a goal-oriented approach tailored to individual patient in order to provide the highest quality of life possible in the last phase of their disease. 